\title{
The Diagnosis of Thoracic Malignant Mesothelioma: Practical Considerations and Recent Developments
}

\author{
Torasik Malign Mezotelyoma Tanısı: \\ Pratik Yaklaşımlar ve Yeni Gelişmeler
}

\author{
Maxwell SMITH, Thomas COLBY
}

Mayo Clinic Arizona, Laboratory Medicine and Pathology, SCOTTSDALE, USA

\begin{abstract}
Pleural biopsies for the evaluation of malignant mesothelioma can be some of the most challenging cases faced by the practicing surgical pathologist. We review the epidemiology, clinical presentation, and imaging studies in patients with malignant mesothelioma, and then present a practical approach to the diagnosis using the cytologic features for malignancy and whether there is an epithelioid or spindled morphology; four main scenarios are discussed. The pertinent immunohistochemical work-up is reviewed for each scenario. Following this general overview, more unusual histologic patterns are compared and unusual presentations are discussed. Brief mention of grading systems for malignant mesothelioma and the use of electron microscopy and molecular studies is made. Practical considerations in the diagnosis of malignant mesothelioma are made throughout.
\end{abstract}

Key Words: Mesothelioma, Thoracic neoplasms, Differential diagnosis, Immunohistochemistry, Pathology

\begin{abstract}
ÖZ
Malign mezotelyomayı değerlendirmek için yapılan plevral biyopsiler, patoloji uzmanlarının karşılaştığı en karmaşık olgulardan birisi olabilir. Malign mezotelyomalı hastalarda epidemiyoloji, klinik görünüm ve görüntüleme çalışmalarını gözden geçirdik ve ardından hem epitelioid hem de spindle morfoloji için malignitenin sitolojik özellikleri kullanarak tanıya pratik bir yaklaşım sunduk; dört ana senaryo tartıştık. Her bir senaryo için uygun immünohistokimyasal çalışmalar gözden geçirildi. Genel değerlendirmeden sonra, daha sıradışı histolojik paternler karşılaştırıldı ve sıradışı görünümler tartışıldı. Malign mezotelyomal için sınıflandırma sistemleri, elektron mikroskop kullanımı ve moleküler çalışmalar özetlendi. Malign mezotelyomal tanısına pratik yaklaşımlar makale boyunca irdelendi.
\end{abstract}

Anahtar Sözcükler: Mezotelyoma, Torasik tümörler, Ayırıcı tanı, İmmünohistokimya, Patoloji

disease with median survival of twelve to eighteen months. Epithelioid types have a slightly better prognosis than sarcomatoid/desmoplastic variants.

\section{Pathologic Diagnosis of Malignant Mesothelioma}

In most cases, the pathologic diagnosis of malignant mesothelioma is straightforward: the radiologic/gross examination shows the characteristic encasement of the lung with pleural thickening and/or nodular studding and histology that is distinctive and readily interpreted as mesothelial. The diagnosis of MM requires microscopic evaluation of pleural tissue specimens. In many cases, because the histology is characteristic for both malignancy and mesothelial origin, immunohistochemical analysis is a confirmatory exercise, although use of immunohistochemistry has become the diagnostic standard in the diagnosis of MM. Occasionally one encounters cases

Correspondence: Maxwell SMITH

Mayo Clinic Arizona, Laboratory Medicine and Pathology,

SCOTTSDALE, USA

E-mail: smith.maxwell@mayo.edu Phone: +11 4803014439 
in which the immunohistochemical evaluation does not confirm the H\&E impression.

The presence or absence of frankly malignant cytology and the presence or absence of spindle cell/sarcomatoid histology will direct the differential diagnosis and immunohistochemical analysis, as described below. Regardless of the cytologic features, the presence of mesothelial cells invading adjacent structures such as subpleural adipose tissue or lung parenchyma, confirms a diagnosis of malignancy. Figure 1A-D shows the four basic histologic presentations of MM and Table I highlights the differential diagnosis in each setting.

\section{Malignant epithelioid cytology: Differential diagnosis includes MM and carcinoma (or rarely melanoma and some sarcomas)}

This is the most common histologic problem encountered by the surgical pathologist interpreting pleural biopsies. The histology shows obviously malignant epithelioid cells and the differential diagnosis is $\mathrm{MM}$ versus carcinoma, most commonly metastatic adenocarcinoma from the lung. Histologic structures favoring carcinoma include glandular formation and mucin production. In this setting however, there are several IHC markers that can help in the distinction (1) (Figure 2). As the figure demonstrates, no antibody has perfect sensitivity and specificity and the frequency of positivity decreases with decreasing differentiation. In addition, in practice, there is often variability of expression through each tumor, a factor to remember when dealing with small biopsy specimens. There is also demonstrated variability between different laboratories (2). For these reasons, a panel of at least two stains for each diagnosis (MM vs the alternative consideration which in most cases is metastatic lung carcinoma) is usually recommended. At our institution, our MM panel consists of AE1/AE3 to confirm staining and assess the infiltrate architecture, calretinin, CK5/6, WT-1, and sometimes D2-40 as the "mesothelial markers", and MOC-31, CEA(m), TTF-1, and sometimes B72.3 and CD15 as the "carcinoma markers".

When selecting a panel of stains in this setting, it is also important to consider the site and sex of the patient as well. Metastatic prostatic or mammary carcinoma to the pleura may mimic MM and thus PSA and ER/CGDFP- 15 may be useful. WT-1 is unlikely to be useful if ovarian type serous carcinoma is a consideration.

In considering the staining results, it is not uncommon for one or several stains to give incongruous or conflicting results. In this setting, one must try to prioritize the immunostaining results. For example, a potentially aberrant TTF-1 stain in a MM would give us far greater pause in considering a diagnosis of $\mathrm{MM}$, compared to an aberrant MOC-31 stain. If the stain results do not fit, we always resort back to our original H\&E impression and reconsider the clinical/radiographic evidence. In practice, some cases are simply inconclusive and we are left with "malignant tumor, metastatic carcinoma favored over MM" (or vice versa).

\section{Malignant spindled/fibroblastic cytology: Differential diagnosis includes sarcomatoid MM, sarcomatoid carcinoma, sarcoma, (and rarely melanoma).}

In these cases, the cells are overtly malignant but do not show any epithelioid differentiation and typically have a spindled morphology. Determining the origin on the malignant cells in this setting can be very difficult, even with immunohistochemical assistance. It may be easy to exclude a metastatic malignant melanoma with S-100, HMB-45, and MART-1 stains, but the distinction between sarcomatoid MM, sarcomatoid carcinoma, and

Table I: Differential diagnosis of MM dichotomized based on cytologic suspicion for malignancy and epithelioid or spindled morphology

\begin{tabular}{|l|l|l|l|}
\hline \multicolumn{2}{|c|}{} & \multicolumn{2}{|l|}{ Epithelioid or Spindled Morphology } \\
\cline { 3 - 4 } & Epithelioid & Spindled \\
\hline \multirow{2}{*}{$\begin{array}{l}\text { Cytologic } \\
\begin{array}{l}\text { Suspicion for } \\
\text { Malignancy }\end{array}\end{array}$} & $\begin{array}{l}\text { Low } \\
\text { (mild atypia at most) }\end{array}$ & $\begin{array}{l}\text { MM } \\
\text { Reactive mesothelial cell } \\
\text { hyperplasia }\end{array}$ & $\begin{array}{l}\text { Desmoplastic MM } \\
\text { Fibrous pleurisy }\end{array}$ \\
\cline { 2 - 4 } & $\begin{array}{l}\text { High } \\
\text { (overtly malignant) }\end{array}$ & $\begin{array}{l}\text { MM } \\
\text { Carcinoma, esp } \\
\text { adenocarcinoma }\end{array}$ & $\begin{array}{l}\text { Sarcomatoid MM } \\
\text { Sarcomatoid carcinoma } \\
\text { Sarcoma } \\
\text { Melanoma }\end{array}$ \\
\hline
\end{tabular}


sarcoma is usually not easy. Figure 3 highlights some of the immunohistochemical findings in these cases. TTF-1, CEA, CD15, and MOC-31 are typically not helpful. Notice in particular the similarities between sarcomatoid MM and sarcomatoid carcinoma. There are really not any reliable stains that can help in this differential diagnosis. In practice, one must individualize each case taking into consideration the gross/radiologic findings, the routine histology, and the immunohistochemistry.

\section{Bland epithelioid cytology: Differential diagnosis includes $M M$ and reactive mesothelial cell hyperplasia}

In this setting, where one knows that the process is
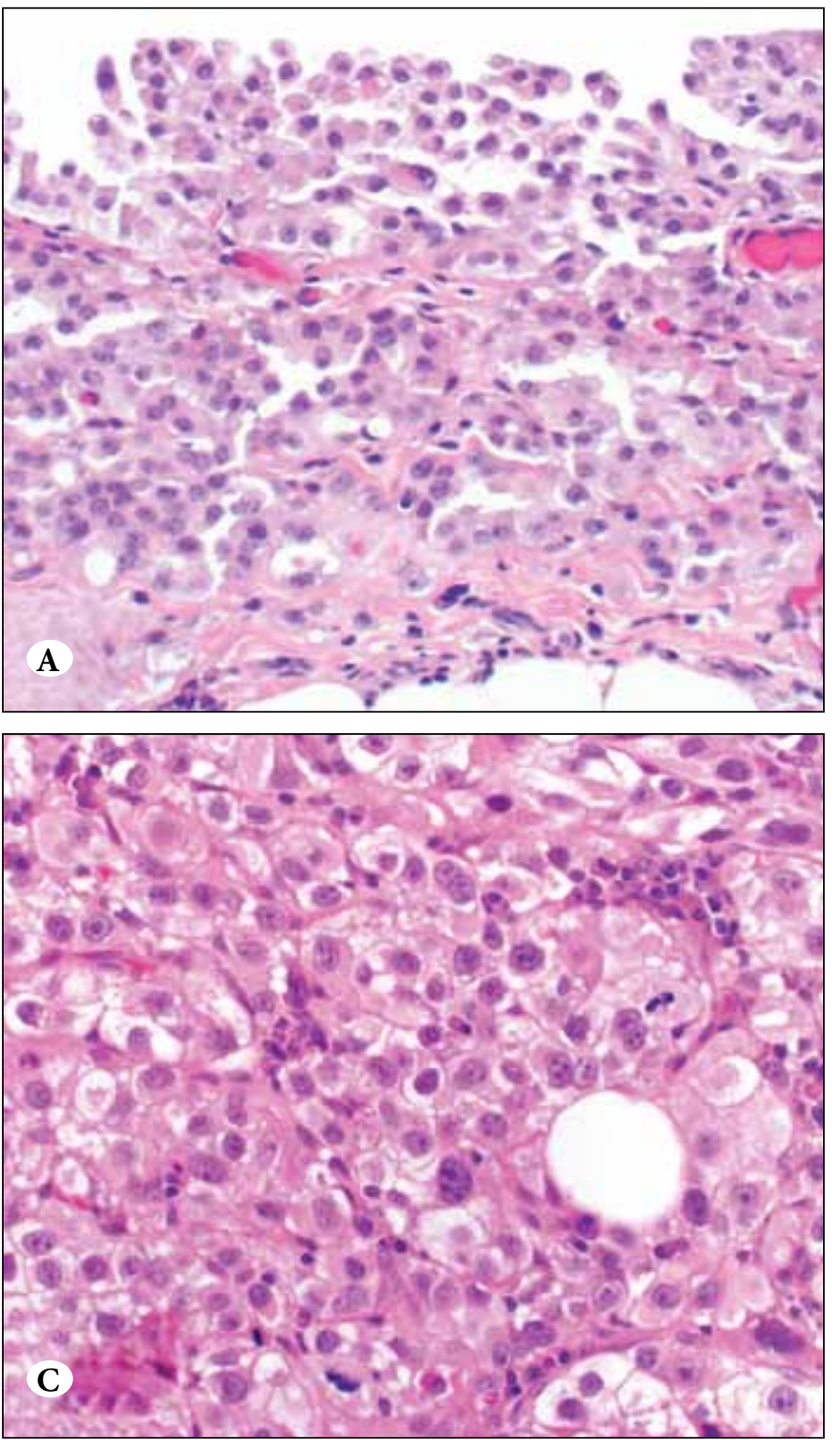

mesothelial, arriving at a final diagnosis is mostly done with standard H\&E histology because the architectural pattern of growth is the most helpful feature in establishing a diagnosis of MM. Architecture that favors MM includes a disorganized growth pattern, stromal invasion, and complex architectural patterns such as papillae, tubules, and stratification (Figure 4A, B) (3). Necrosis is not often seen, but if it is present, also favors MM. Conversely, although some cases of benign mesothelial hyperplasia may show dramatic cellularity, the proliferation is usually confined to the pleural surface and does not show any stromal invasion. In this setting, the presence of mitotic figures is not helpful in the differential diagnosis.
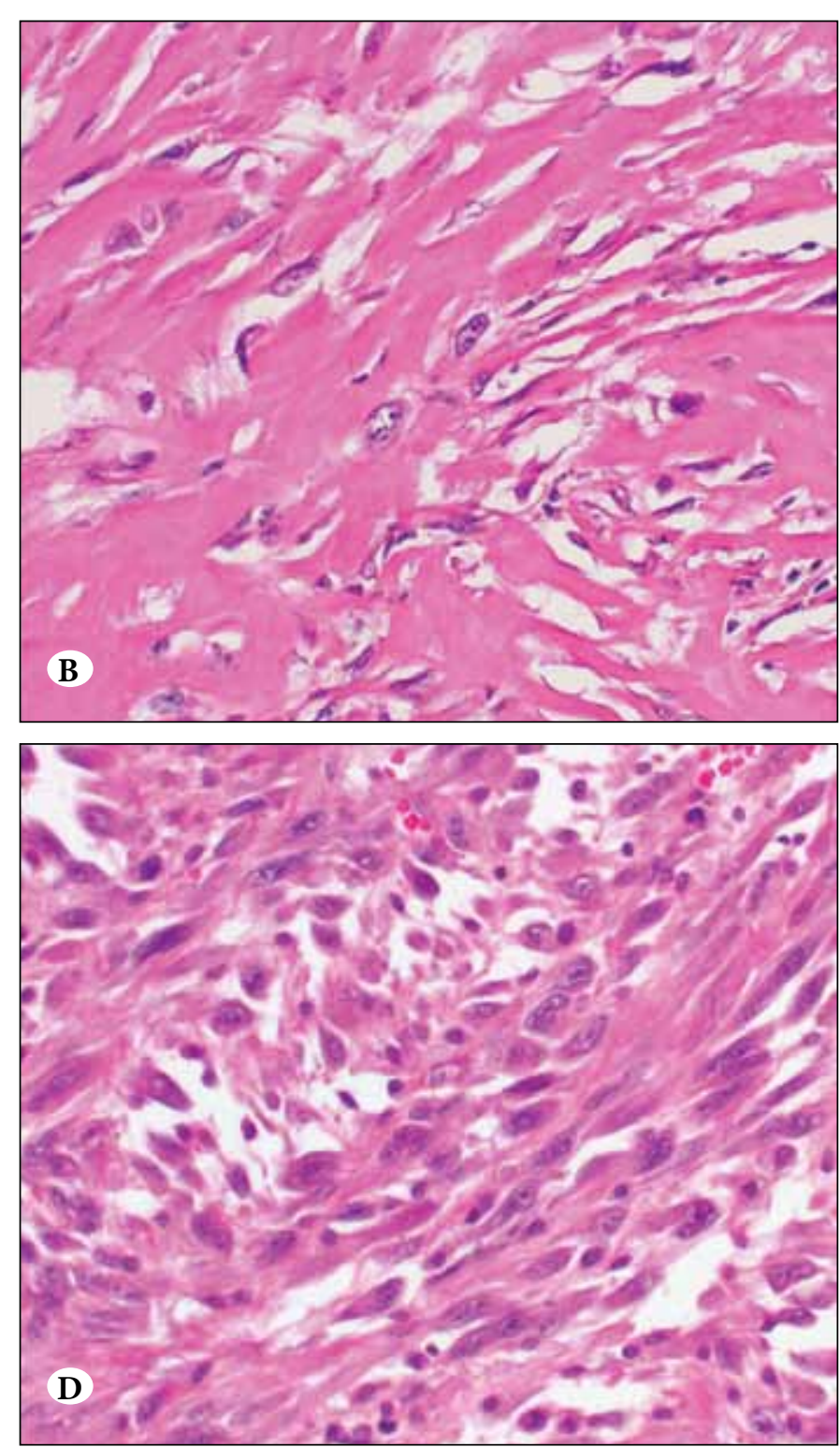

Figure 1: Diverse morphology of MM including bland epithelioid (A, H\&E x200), bland spindled (B, H\&E x400), malignant epithelioid (C, H\&E x400), and malignant spindled (D, H\&E x400). 

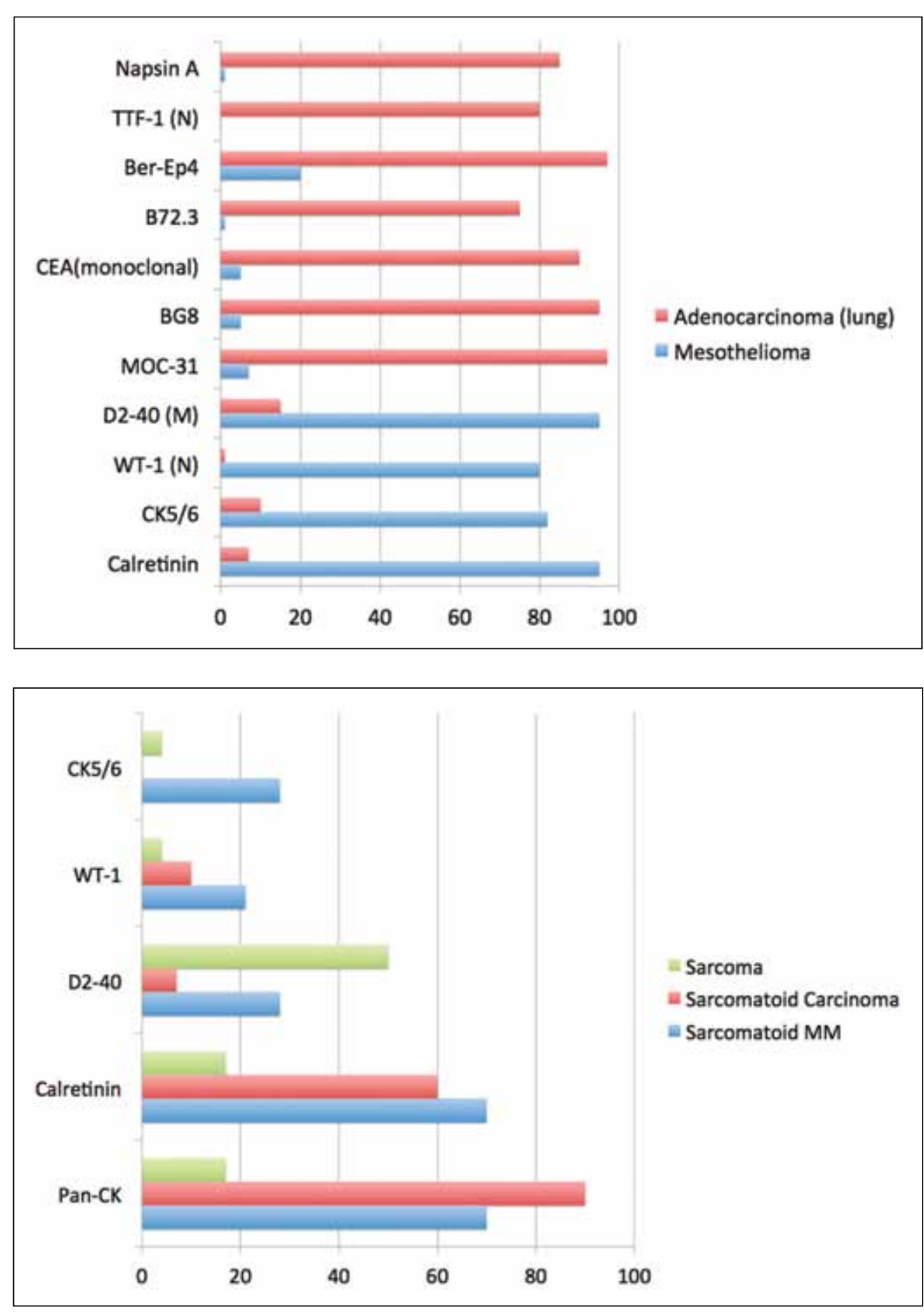

Figure 2: Relative Percentage of mesothelioma and lung adenocarcinoma expressing the various IHC markers. Staining is cytoplasmic unless otherwise noted $(\mathrm{N}=$ nuclear, $\mathrm{M}=$ membranous). Data adapted from Husain et al. (1).
Figure 3: Relative percentage of reactivity in sarcoma, sarcomatoid carcinoma, and sarcomatoid MM. Adapted from Lucas DR et al. (29).
We find pankeratin staining (eg. AE1/AE3) useful in this setting: one can readily assess the architecture and the pattern of growth from low-power (Figure 4C,D), especially in settings in which there is associated inflammation or histiocytic reaction. In MM there is irregular growth into stroma with the aforementioned patterns. Reactive mesothelial hyperplasia shows zonation with smooth planes of keratin reactivity and parallel arrays of the keratin positive cells. In some cases one can find entrapped benign epithelioid mesothelial cell deep within a fibrotic pleural lesion, but they are usually cytologically bland simple gland-like structures arranged in a linear fashion along what was once the pleural surface, but which now has overlying fibrosis. 

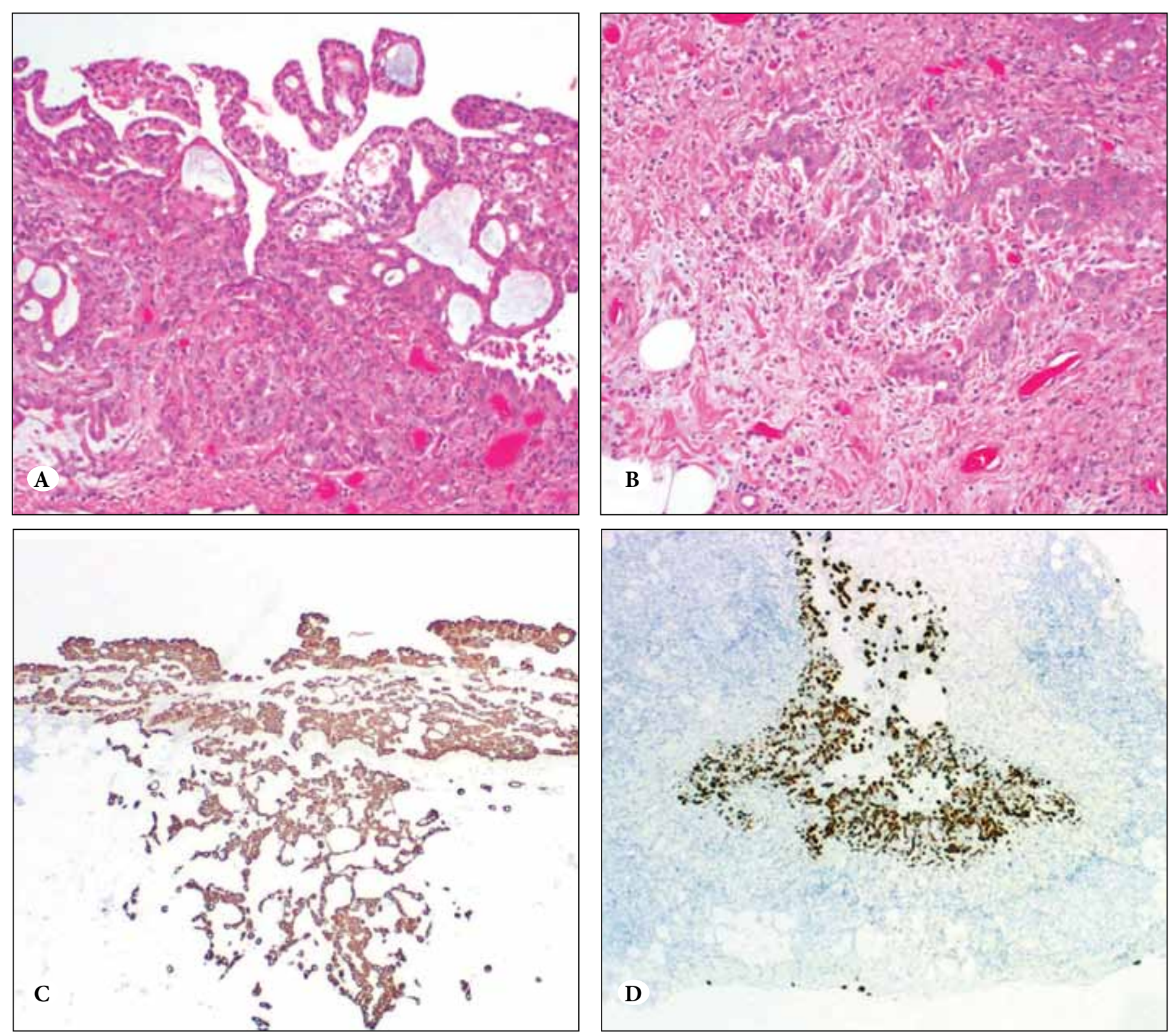

Figure 4: Features that are helpful in establishing a diagnosis of $\mathrm{MM}$ in the setting of bland epithelioid histology include complex architectural patterns such as papilla and tubules (A, H\&E x100) and stromal invasion (B, H\&E x200). AE1/AE3 immunohistochemical stains highlighting invasion in a MM (C, AE1/AE3 x100) and benign mesothelial cell hyperplasia confined to the pleural surface (D, AE1/AE3 x40).

Some have suggested IHC as an adjunct to the problem of mesothelial hyperplasia versus mesothelioma, and suggested markers have included desmin, EMA, p53, GLUT-1, IMP3, CD146, and CD147 (1, 4, 5), however, lack of sufficient sensitivity, specificity, and availability makes the use of IHC unsatisfactory in the individual patient. In our practice, stromal invasion is most useful diagnostic feature of MM. However, if stromal invasion is not seen, we may still cautiously consider the diagnosis of MM if there are bulky pleural masses and compelling cytologic features. Invasion of the visceral pleura is usually a late manifestation of MM. When this occurs, the invading cells can be deceptively bland appearing cytologically as them become more attenuated. There is typically no desmoplastic or inflammatory reaction when MM invades the visceral pleural. An even later finding is lymphangitic spread of MM. This is easily appreciated with staining for calretinin as none of the surrounding lung parenchyma shows any staining. 


\section{Bland spindled cytology: Differential diagnosis includes desmoplastic MM and fibrous pleurisy}

When faced with bland spindled cytology in pleural biopsies, the differential diagnosis primarily includes desmoplastic MM and fibrous pleurisy. The 2004 WHO classification (REF) defines desmoplastic $\mathrm{MM}$ as a sarcomatoid mesothelioma with greater than 50\% dense collagenous stroma and haphazardly arranged slit-like spaces made up of cells with only slightly atypical nuclei (Figure 1B). Conversely, fibrous pleurisy consists of thickened pleura composed of fibrous tissue without elastic fibers (Figure
5A). There may be variable degrees of inflammation and fibroblastic proliferation. Care should be taken not to over interpret any gross or radiographic findings as they may fool even the most experienced surgeons and radiologists. Key histologic features in the distinction between these entities include bland necrosis (Figure 5C), stromal invasion (Figure 5D), and the presence, at least focally, of frankly sarcomatoid areas (3). Mangano et al. (6) studied 31 cases and found that invasion of chest wall or lung, bland necrosis, sarcomatoid areas, and distant metastases correlated with the diagnosis of desmoplastic MM. They
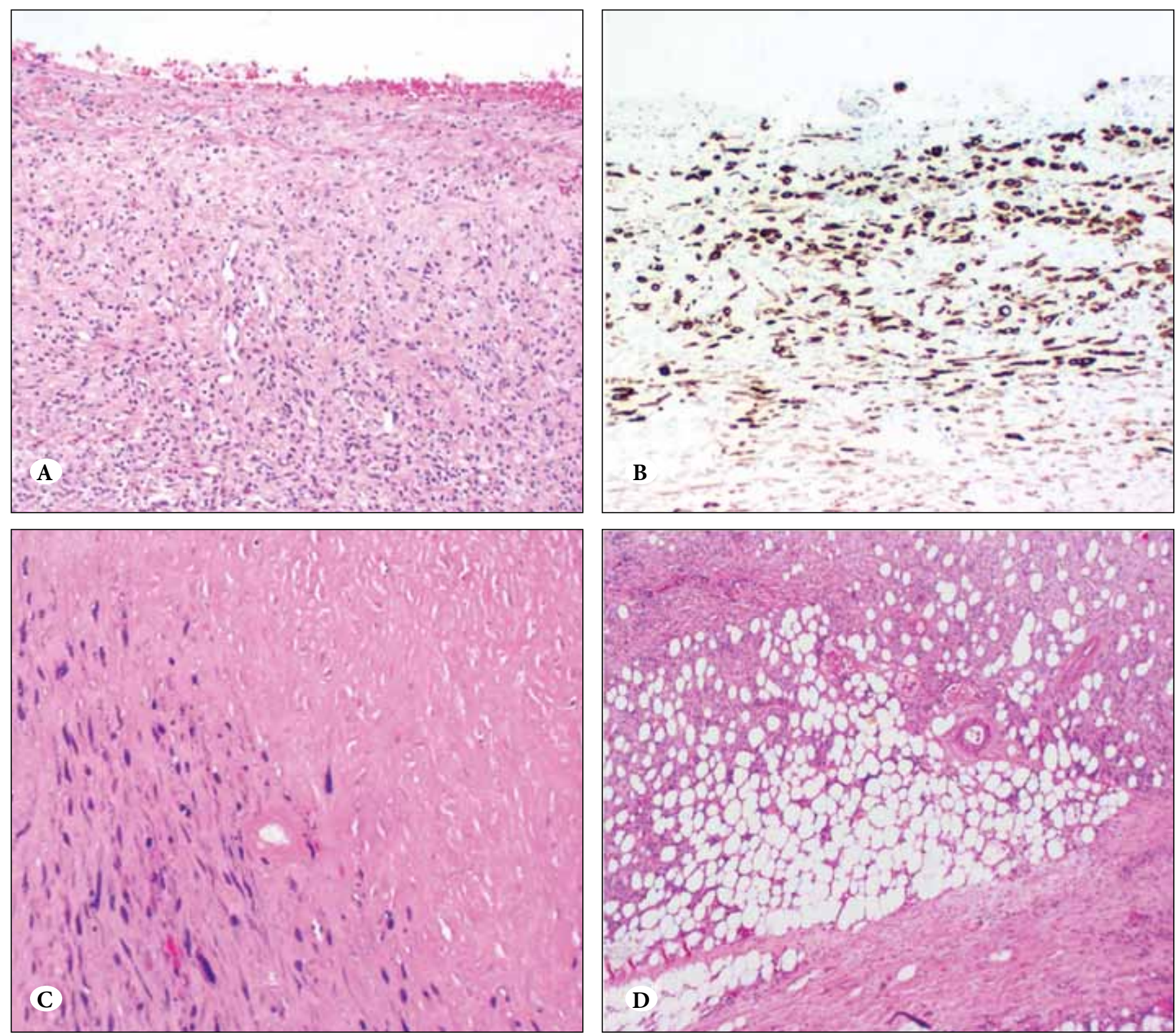

Figure 5: Fibrous pleurisy can show a thickened pleural surface with inflammation and fibroblasts (A, H\&E x40). AE1/AE3 stains will highlight keratin positive cells in a layered pattern parallel to the original pleural surface in benign fibrous pleurisy (B, AE1/AE3 x100). Hallmarks of desoplastic MM include bland necrosis (C, H\&E x200) and stromal infiltration (D, H\&E x40). 
found all patients without these findings were alive 6-45 months after diagnosis (median 20 mos) whereas 23 of 24 diagnosed as DMM were dead of their disease, and one was alive with disease at 8 days to 19 months follow up ( median 6 months). This highlights the dismal outcome associated with desmoplastic MM.

From an immunohistochemical perspective the only consistently helpful stain is this situation is pankeratin such as AE1/AE3. The stain is not used so much to look for positive cells since both reactive/benign and malignant cells will stain but to to characterize the architecture of the infiltrate and to show the presence of invasion. Desmoplastic MM will show a disorderly proliferation with abrupt transitions in cellularity and invasion of the chest wall or lung compared to fibrous pleurisy which shows more of a zonal distribution of AE1/AE3 positive cells (Figure 5B).

\section{Unusual Histologic Patterns of MM}

A variety of unusual patterns of $\mathrm{MM}$ have identified. It is important to remember $\mathrm{MM}$ as a possibility when encountering an unusual appearing tumor in an unusual location. Table II reviews several sub-types of MM with unusual patterns, describes the histology, outlines the major differential diagnostic entities, and provides references for further exploration.

\section{Testing of MM Beyond H\&E and Immunohistochemistry}

Both electron microscopy (EM) and molecular markers have been used in the evaluation and diagnosis of MM. While the typical electron microscopy findings of MM, including apical, long, and thin microvilli without a glycocalyx, have long since been described, tumors that have characteristic EM findings are usually better differentiated epithelioid MM where the diagnosis is made faster and more inexpensively with immunohistochemistry. We almost never perform EM in cases of suspected MM. Molecular markers have also been studies in the evaluation of MM. The 9p21 locus harboring the CDKN2A/p16 gene has been reported to show homozygous deletions in some cases of MM and has been associated with a more favorable prognosis. This has led some to suggest a diagnostic and prognostic utility to $9 \mathrm{p} 21$ deletion testing (7). Jean et al. showed a subset of MM with inactivation of the tumor suppressor genes at the INK4 and NF2 loci (8). At this time, we do not use molecular techniques in routine practice either for diagnosis or prognosis.

\section{Unusual Patterns of Presentation of MM}

MM usually presents as a diffuse or multifocal disease process involving the pleura, peritoneum, or pericardium.
Only rarely do patients present with lymphadenopathy, signs/symptoms of interstitial lung disease, or with localized lesions.

Patients with localized lesions seem to have an improved prognosis. In the studies by Crotty et al. (9) and Allen et al. (10) 28 cases of localized MM were evaluated in 19 males and 9 females with a mean age of presentation in the 60's (range of 37-83). Most cases with of pleural origin and ranged in size from 2.8 to $10.0 \mathrm{~cm}$. Some showed a pedunculated appearance. Most were typical epithelioid $\mathrm{MM}$ and a third showed biphasic morphology. No unique immunohistochemical findings were identified. Ten were dead of disease while one died form other causes and 6 were alive and well.

It is very rare for MM to present initially with lymph node metastases. Sussman et al. reported six cases, 5 of which were form the peritoneal surface, suggesting a higher frequency compared to pleural based MM (11). It should be noted that benign mesothelial cells may be found in lymph nodes, particularly in patients with chronic serosal inflammation $(12,13)$. This presents a pitfall for surgical pathologists, particularly in the setting of sentinel lymph node evaluation with immunohistochemistry (14).

Finally, Larsen et al. recently described a series of five patients who presented with signs and symptoms of interstitial lung disease and were found to have diffuse intrapulmonary mesothelioma (15). In this series a variety of histologic patterns were mimicked by $M M$, including adenocarcinoma-like, desquamative interstitial pneumonia like, pulmonary Langerhans cell histiocytosis like, organizing pneumonia-like, and silicotic nodule-like.

\section{Grading MM}

Kadota et al (16) recently developed a three tiered grading system for MM suggesting that nuclear grading may help in prognostication. They studied 232 epithelioid MM and assessed them for nuclear atypia, nuclear to cytoplasmic ratio, chromatin, nuclear inclusions, nucleoli, mitoses, atypical mitoses, and Ki-67 labeling. Both nuclear atypia and mitotic count showed correlation with survival following multivariate analysis. Using a simple mild, moderate, severe nuclear grading system, median overall survival ranged from 23, 15, and 8 months, respectively (16).

\section{CONCLUSIONS}

In conclusion, we have highlighted the difference in the differential diagnosis of MM based on the presence or absence of malignant features as well as epithelioid or spindled morphology. The immunohistochemical 
Table II: MM with unusual pathology

\begin{tabular}{|c|c|c|c|}
\hline MM with Unusual Pathology & Description of the Histology & Diagnostic Pitfalls & References \\
\hline $\begin{array}{l}\text { Mesothelioma with heterologous } \\
\text { elements }\end{array}$ & $\begin{array}{l}\text { Typical epithelioid or sarcomatoid MM } \\
\text { may show a variety of epithelioid or } \\
\text { mesenchymal differentiation which } \\
\text { can cause problems on small biopsy } \\
\text { specimens. }\end{array}$ & Many sarcomas & 18 \\
\hline $\begin{array}{l}\text { Mesothelioma with } \\
\text { angiosarcomatous component }\end{array}$ & Angiosarcomatous differentiation & High-grade angiosarcoma & 19 \\
\hline Deciduoid mesothelioma & $\begin{array}{l}\text { Large, eosinophilic, polygonal cells with } \\
\text { one or more nuclei. }\end{array}$ & $\begin{array}{l}\text { Metastatic trophoblastic } \\
\text { disease, especially in a } \\
\text { female }\end{array}$ & 20 \\
\hline Signet ring mesothelioma & $\begin{array}{l}\text { Cytoplasmic vacuolization causing the } \\
\text { nucleus to be pushed to the periphery. }\end{array}$ & Signet ring cell carcinoma & 21 \\
\hline Biphasic Mesothelioma & $\begin{array}{l}\text { Biphasic tumor consisting of both } \\
\text { spindled stromal elements and areas of } \\
\text { epithelioid morphology }\end{array}$ & synovial sarcoma & 22 \\
\hline Lymphohistiocytoid & $\begin{array}{l}\text { Histiocyte-like appearing mesothelial } \\
\text { cells with dense associated lymphoid } \\
\text { infiltrate }\end{array}$ & $\begin{array}{l}\text { Lymphoma or } \\
\text { lymphoproliferative disease }\end{array}$ & 23 \\
\hline Adenomatoid & $\begin{array}{l}\text { Proliferation of epithelioid cells in } \\
\text { a tubular architecture similar to an } \\
\text { adenomatoid tumor of the genital tract }\end{array}$ & $\begin{array}{l}\text { Adenomatoid tumor, } \\
\text { metastatic carcinoma }\end{array}$ & 24 \\
\hline $\begin{array}{l}\text { Epithelioid } \\
\text { hemangioendothelioma-like } \\
\text { mesothelioma }\end{array}$ & Epithelioid cells with vacuoles & $\begin{array}{l}\text { Epithelioid } \\
\text { hemangioendothelioma }\end{array}$ & \\
\hline $\begin{array}{l}\text { Multicystic mesothelioma (very } \\
\text { rare in the pleura, more common } \\
\text { in peritoneum) }\end{array}$ & $\begin{array}{l}\text { Tumor with multiple, usually small, cysts } \\
\text { lined by a single layer of mesothelial cells } \\
\text { without atypia. Usually no definitive } \\
\text { invasion. Uncertain malignant potential. }\end{array}$ & & 25,26 \\
\hline $\begin{array}{l}\text { Osteosarcomatous/ } \\
\text { chondrosarcomatous }\end{array}$ & $\begin{array}{l}\text { Areas of definitive osteoid or } \\
\text { cartilaginous matrix production. }\end{array}$ & $\begin{array}{l}\text { Osteosarcoma } \\
\text { Chondrosarcoma }\end{array}$ & 18 \\
\hline $\begin{array}{l}\text { Mesotheliomas with myxoid } \\
\text { stroma }\end{array}$ & $\begin{array}{l}\text { Tumor with greated than } 50 \% \text { myxoid } \\
\text { stroma. Cells show epithelioid } \\
\text { morphology and showed surface } \\
\text { microvilli of mesothelial cells. }\end{array}$ & $\begin{array}{l}\text { Liposarcoma } \\
\text { Myxoid chondrosarcoma }\end{array}$ & 27 \\
\hline $\begin{array}{l}\text { Mesothelioma with osteoclastic } \\
\text { giant cells }\end{array}$ & $\begin{array}{l}\text { Pleomorphic tumor with admixed giant } \\
\text { cells with an osteoclast like appearance. } \\
\text { Focal hemorrhage and necrosis has been } \\
\text { described. }\end{array}$ & $\begin{array}{l}\text { Giant-cell tumors } \\
\text { Pleomorphic sarcomas }\end{array}$ & 28 \\
\hline
\end{tabular}


evaluation must be tailored to the basic morphologic pattern (spindled vs epithelioid) and the clinical setting (sex, site, prior history of neoplasm, etc.).

\section{REFERENCES}

1. Husain AN, Colby T, Ordonez N, Krausz T, Attanoos R, Beasley MB, Borczuk AC, Butnor K, Cagle PT, Chirieac LR, Churg A, Dacic S, Fraire A, Galateau-Salle F, Gibbs A, Gown A, Hammar S, Litzky L, Marchevsky AM, Nicholson AG, Roggli V, Travis WD, Wick M; International Mesothelioma Interest Group. Guidelines for pathologic diagnosis of malignant mesothelioma: 2012 update of the consensus statement from the International Mesothelioma Interest Group. Arch Pathol Lab Med. 2013; 137:647-67.

2. Betta PG, Magnani C, Bensi T, Trincheri NF, Orecchia S. Immunohistochemistry and molecular diagnostics of pleural malignant mesothelioma. Arch Pathol Lab Med. 2012; 136: 253-61.

3. Husain AN, Colby TV, Ordóñez NG, Krausz T, Borczuk A, Cagle PT, Chirieac LR, Churg A, Galateau-Salle F, Gibbs AR, Gown AM, Hammar SP, Litzky LA, Roggli VL, Travis WD, Wick MR. Guidelines for pathologic diagnosis of malignant mesothelioma: A consensus statement from the International Mesothelioma Interest Group. Arch Pathol Lab Med. 2009; 133:1317-31.

4. Pinheiro C, Longatto-Filho A, Soares TR, Pereira H, Bedrossian C, Michael C, Schmitt FC, Baltazar F. CD147 immunohistochemistry discriminates between reactive mesothelial cells and malignant mesothelioma. Diagnostic Cytopathology. 2012; 40:478-83.

5. Sato A, Torii I, Okamura Y, Yamamoto T, Nishigami T, Kataoka TR, Song M, Hasegawa S, Nakano T, Kamei T, Tsujimura T. Immunocytochemistry of CD146 is useful to discriminate between malignant pleural mesothelioma and reactive mesothelium. Mod Pathol. 2010; 23:1458-66.

6. Mangano WE, Cagle PT, Churg A, Vollmer RT, Roggli VL. The diagnosis of desmoplastic malignant mesothelioma and its distinction from fibrous pleurisy: A histologic and immunohistochemical analysis of 31 cases including p53 immunostaining. Am J Clin Pathol. 1998; 110:191-9.

7. Chiosea S, Krasinskas A, Cagle PT, Mitchell KA, Zander DS, Dacic S. Diagnostic importance of 9p21 homozygous deletion in malignant mesotheliomas. Mod Pathol. 2008; 21:742-7.

8. Jean D, Daubriac J, Le Pimpec-Barthes F, Galateau-Salle F, Jaurand MC. Molecular changes in mesothelioma with an impact on prognosis and treatment. Arch Pathol Lab Med. 2012; 136: 277-93.

9. Crotty TB, Myers JL, Katzenstein AL, Tazelaar HD, Swensen SJ, Churg A. Localized malignant mesothelioma. A clinicopathologic and flow cytometric study. Am J Surg Pathol. 1994; 18:357-63.

10. Allen TC, Cagle PT, Churg AM, Colby TV, Gibbs AR, Hammar SP, Corson JM, Grimes MM, Ordonez NG, Roggli V, Travis WD, Wick MR. Localized malignant mesothelioma. Am J Surg Pathol. 2005; 29:866-73.

11. Sussman J, Rosai J. Lymph node metastasis as the initial manifestation of malignant mesothelioma. Report of six cases. Am J Surg Pathol. 1990; 14:819-28.
12. Argani P, Rosai J. Hyperplastic mesothelial cells in lymph nodes: Report of six cases of a benign process that can stimulate metastatic involvement by mesothelioma or carcinoma. Hum Pathol. 1998; 29:339-46.

13. Brooks JS, LiVolsi VA, Pietra GG. Mesothelial cell inclusions in mediastinal lymph nodes mimicking metastatic carcinoma. Am J Clin Pathol. 1990; 93:741-8.

14. Parkash V, Vidwans M, Carter D. Benign mesothelial cells in mediastinal lymph nodes. Am J Surg Pathol. 1999; 23:1264-9.

15. Larsen BT, Klein JR, Hornychová H, Nuti R, Thirumala S, Leslie KO, Colby TV, Tazelaar HD. Diffuse intrapulmonary malignant mesothelioma masquerading as interstitial lung disease: A distinctive variant of mesothelioma. Am J Surg Pathol. 2013; 37:1555-64.

16. Kadota K, Suzuki K, Colovos C, Sima CS, Rusch VW, Travis WD, Adusumilli PS. A nuclear grading system is a strong predictor of survival in epitheloid diffuse malignant pleural mesothelioma. Mod Pathol. 2012; 25:260-71.

17. Klebe S, Griggs KM, Ely M, Henderson DW. Is there a need for expert opinion for biopsy diagnosis of difficult cases of malignant mesothelioma? Pathology. 2012;4 4:562-3.

18. Klebe S, Mahar A, Henderson DW, Roggli VL. Malignant mesothelioma with heterologous elements: Clinicopathological correlation of 27 cases and literature review. Mod Pathol. 2008; 21:1084-94.

19. Klabatsa A, Nicholson AG, Dulay K, Rudd RM, Sheaff MT. Diffuse pleural mesothelioma with epithelioid and angiosarcomatous components-a hitherto undescribed pattern of differentiation. Histopathology. 2012; 60:1164-6.

20. Ordóñez NG. Deciduoid mesothelioma: Report of 21 cases with review of the literature. Mod Pathol. 2012; 25:1481-95.

21. Ordóñez NG. Mesothelioma with signet-ring cell features: Report of 23 cases. Mod Pathol. 2013; 26:370-84.

22. Arora SK, Srinivasan R, Nijhawan R, Bansal D, Menon P. Malignant biphasic peritoneal mesothelioma in a child: Fine-needle aspiration cytology, histopathology, and immunohistochemical features along with review of literature. Diagn Cytopathol. 2012; 40:1112-5

23. Galateau-Sallé F, Attanoos R, Gibbs AR, Burke L, Astoul P, Rolland P, Ilg AG, Pairon JC, Brochard P, Begueret H, Vignaud JM, Kerr K, Launoy G, Imbernon E, Goldberg M. Lymphohistiocytoid variant of malignant mesothelioma of the pleura: A series of 22 cases. Am J Surg Pathol. 2007; 31:711-6.

24. Weissferdt A, Kalhor N, Suster S. Malignant mesothelioma with prominent adenomatoid features: A clinicopathologic and immunohistochemical study of 10 cases. Ann Diagn Pathol. 2011; 15:25-9.

25. Ball NJ, Urbanski SJ, Green FH, Kieser T. Pleural multicystic mesothelial proliferation. The so-called multicystic mesothelioma. Am J Surg Pathol. 1990; 14:375-8.

26. Morita S, Goto A, Sakatani T, Ota S, Murakawa T, Nakajima J, Maeda E, Fukayama M. Multicystic mesothelioma of the pericardium. Pathol Int. 2011; 61:319-21. 
27. Shia J, Qin J, Erlandson RA, King R, Illei P, Nobrega J, Yao D, Klimstra DS. Malignant mesothelioma with a pronounced myxoid stroma: A clinical and pathological evaluation of 19 cases. Virchows Arch. 2005; 447:828-34.

28. Itami H, Ohbayashi C, Sakai Y, Kajimoto K, Sakuma T. Pleural malignant mesothelioma with osteoclast-like giant cells. Pathol Int. 2010; 60:217-21.

29. Lucas DR, Pass HI, Madan SK, Adsay NV, Wali A, Tabaczka P, Lonardo F. Sarcomatoid mesothelioma and its histological mimics: A comparative immunohistochemical study. Histopathology. 2003; 42:270-9. 